\title{
A new genus, Neolitochropus (Coleoptera: Cucujoidea: Phalacridae), from the Upper Eocene Bitterfeld amber
}

\section{Новый род Neolitocbropus (Coleoptera: Cucujoidea: Phalacridae) из позАнеэоџенового саксонского янтаря}

\author{
G.Yu. Lyubarsky', E.E. Perkovsky² \\ Г.Ю. Аюбарский ${ }^{1}$, Е.Э. Перковский
}

\begin{abstract}
${ }^{1}$ Zoological Museum of Moscow State University, Bol'shaya Nikitskaya str. 2, Moscow 125009, Russia. E-mail: lgeorgy@rambler.ru Зоологический музей МГУ, ул. Б. Никитская 2, Москва 125009, Россия.

${ }^{2}$ Schmalhausen Institute of Zoology, National Academy of Sciences of Ukraine, Bogdan Khmelnitski str. 15, Kiev 01601, Ukraine. E-mail: perkovsk@gmail.com

Зоологический институт им. И.И. Шмальгаузена НАН Украины, ул. Богдана Хмельницкого 15, Киев 01601, Украина.
\end{abstract}

KEY WORDS: Eocene, amber, Coleoptera, Phalacridae, new genus, new species.

КЛЮЧЕВЫЕ СЛОВА: эоцен, янтарь, Coleoptera, Phalacridae, новый род, новый вид.

ABSTRACT. A new monotypic genus, Neolitochropus gen.n. (type species Neolitochropus hoffeinsorum sp.n.), is described from the Upper Eocene Bitterfeld amber, and compared with other genera of the Litochropus genus group. Extant genera from the Litochropus group are known from the New World, and the Oriental and Australian realms. Neolitochropus is the third beetle genus known only from Bitterfeld, and the first to show tropical biogeographic connections.

РЕЗЮМЕ. Из позднеэоценового саксонского янтаря описан монотипический род Neolitochropus gen.n. (типовой вид Neolitochropus hoffeinsorum sp.n.), проведено сравнение с близкими родами. Близкие роды из группы Litochropus распространены в Новом свете, Ориентальной и Австралийской областях. Neolitochropus - третий род жуков, известный только из саксонского янтаря, и первый, обнаруживающий тропические биогеографические связи.

\section{Introduction}

The shining beetle family (Coleoptera: Cucujoidea: Phalacridae) comprises over 600 species worldwide [Gimmel, 2013: 52 genera, 635 species], and is represented in all biogeographic realms, including 146 species in the Palaearctic region [Švec, 2007]. Imagoes of this family (for example, Olibrus Erichson, 1845) are usually found on flowers, feeding on pollen; larvae either feed in flower heads of Compositae or on spores and stomata of rusts and smuts, or (as in Phalacrus Paykull, 1800, Stilbus Seidlitz, 1872, and Tinodemus Guillebeau, 1894) are associated with pathogenic rust fungi of the order Pucciniales [Steiner, 1984], feeding on their spores. Imagoes and larvae of some genera (Acylomus Sharp, 1888) dwell in leaf litter and within hanging dead-leaf clusters in the grass.
The oldest phalacrid is known from the Albian Spanish amber [Peris et al., 2016]. Besides this record, Phalacridae are known from the Upper Eocene Baltic and Rovno ambers (Phalacrus, Olibrus, and Stilbus; Klebs, 1910; Hieke, Pietrzeniuk, 1984; Lyubarsky, Perkovsky, 2011) and the Middle Miocene Dominican and Mexican ambers [material not determined to generic level for either amber; Spahr, 1981]. Until now, only two fossil phalacrid species have been named: Stilbus bedovoyi Lyubarsky et Perkovsky, 2011 from the Rovno amber, and Olibrus ornatus Foerster, 1891 from the latest Eocene of Brunstatt, in the Rhine valley [Kirejtshuk, Ponomarenko, 2014].

The new genus recorded here belongs to the Litochropus genus group of the Phalacridae [Gimmel, 2013], and was found in the collection of Christel and Hans Werner Hoffeins (Hamburg, Germany, CCHH). This genus group also includes the extant genera Litochropus Casey, 1890, and Neolitochrus Gimmel, 2013, and may be recognized by the following features: head not constricted behind eyes, small scutellar shield, absence of a protibial ctenidium, metatarsomere I as long as or longer than metatarsomere II, and the metaventral lines separated from coxal cavities. Litochropus species are recorded in the New World, and in eastern and northern Australia, New Guinea, and Borneo, whereas species of Neolitochrus are found in the New World and Oriental realms [Thailand: Gimmel, 2013]. The larvae of Litochropus develop in fungi [Xylariaceae: Daldinia, Steiner 1984; Gimmel, 2013] and feed on the corky tissue, whereas adults feed primarily on the spores. The beetles fly into the light at night.

Photographs were taken at Leica stereomicroscope $\mathrm{M} 165 \mathrm{C}$ in the center of the collective usage of the scientific equipment 'Animalia', Shmalhausen Institute of Zoology, National Academy of Sciences of Ukraine, Kiev. 


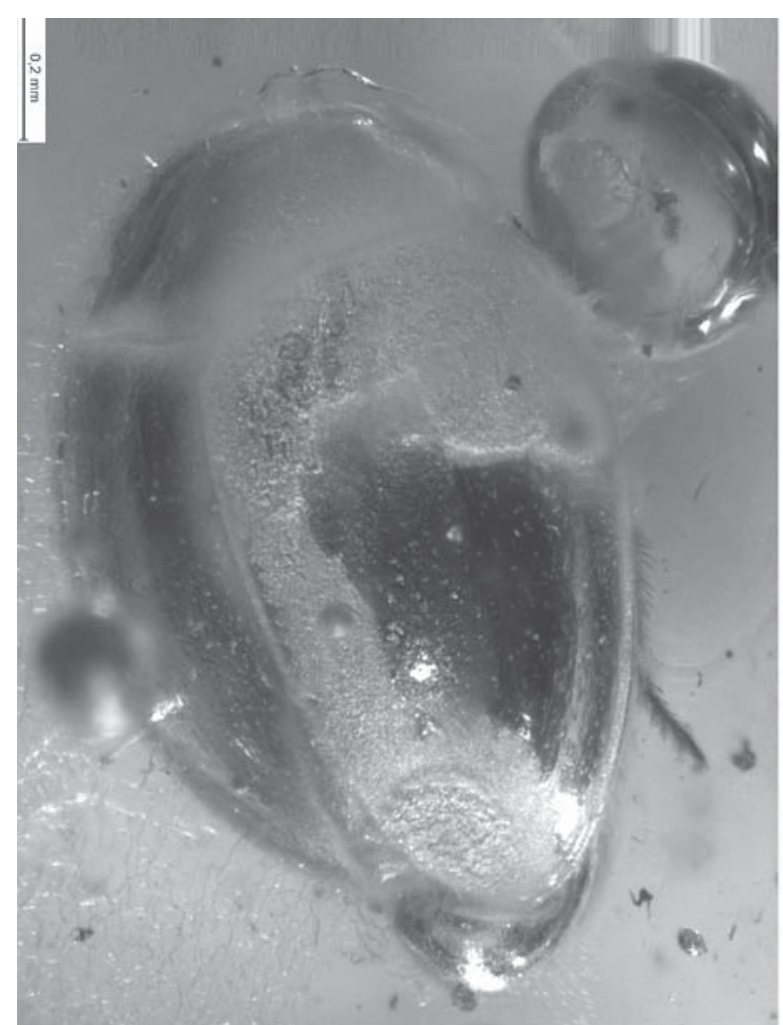

1

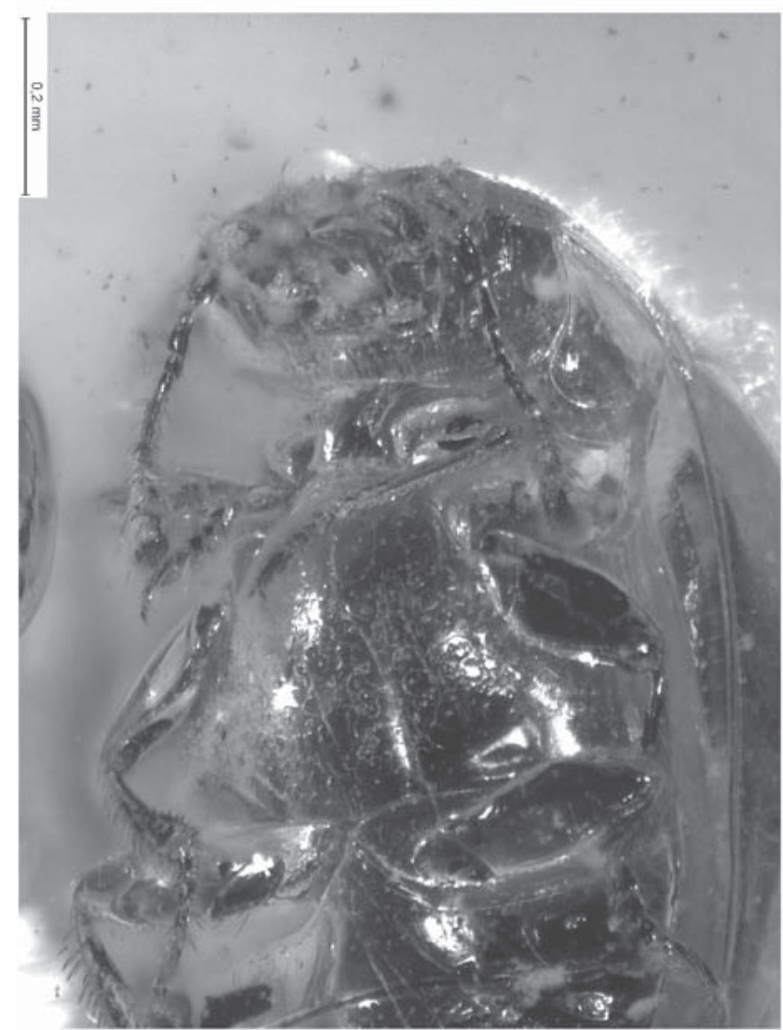

3

Figs 1-4. Neolitochropus hoffeinsorum gen. et sp.n.: 1-2 - habitus, 3 - head and thorax; 4 - head; 1 - dorsal view; 2-4 - ventral view.

Рис. 1-4. Neolitochropus hoffeinsorum gen. et sp.n.: 1-2 - внешний вид; 2 - голова и грудь; 4 - голова; 1 - сверху; 2-4 снизу.

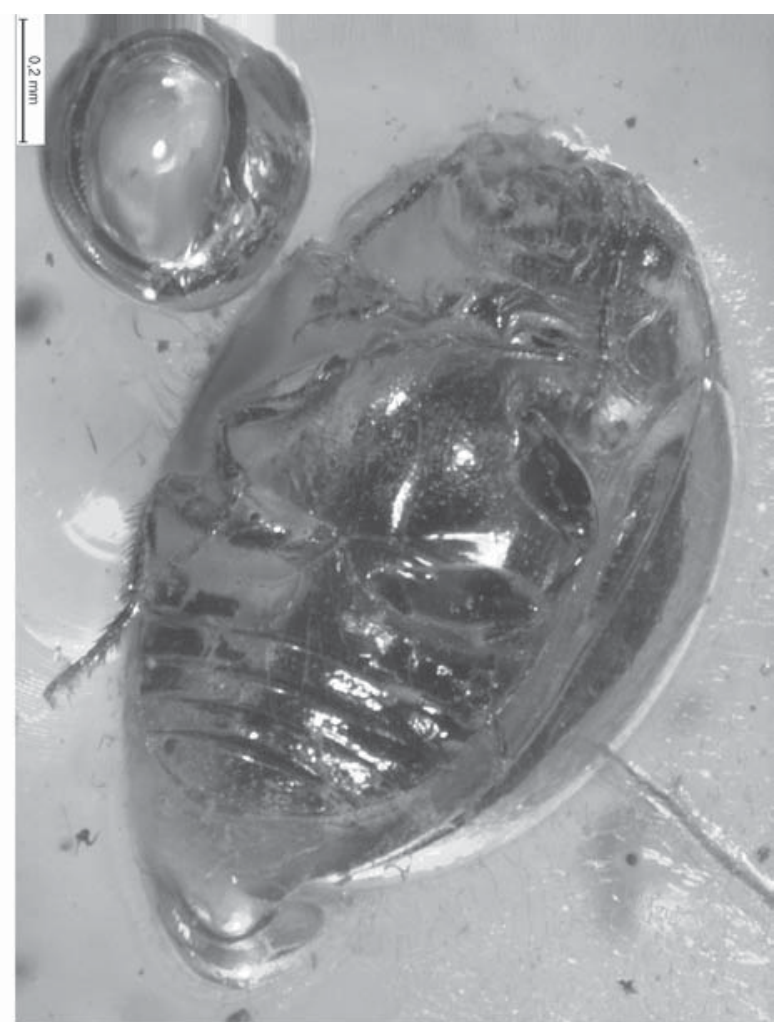

2

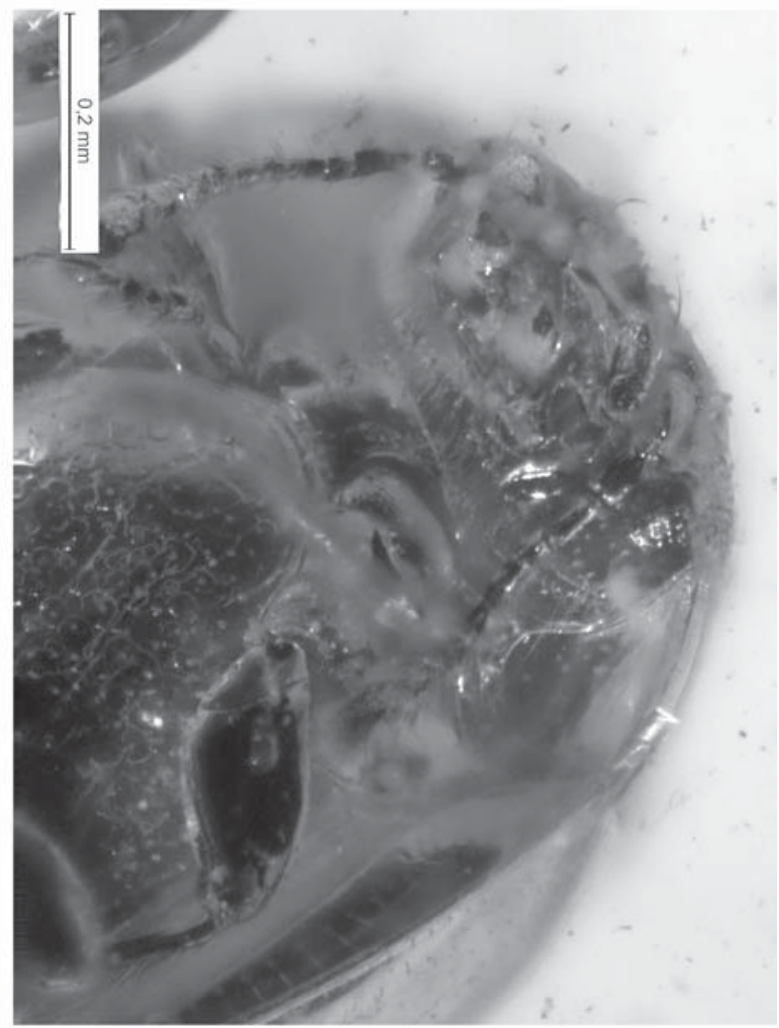

4 


\section{Systematic paleontology}

\section{Family Phalacridae Leach, 1815 \\ Neolitochropus gen.n.}

Type species Neolitochropus hoffeinsorum sp.n.

DIAGNOSIS. Protibial ctenidium absent, without long spines at outer apical angle of protibia and mesotibia, one sutural stria present, metaventral lines separated from coxal cavities, small scutellar shield, metatarsomere I longer than II.

DESCRIPTION. Body short, oval, small, hairless, sclerites weakly brilliant, antennae 11-segmented with 3-segmented club, legs slender. Elytron with weak microsculpture, shagreened, with one sutural stria, weakly disorderly punctured, tarsi 5-5-5.

Head. Eyes small sized; facets convex. Antennal club 3segmented, club weakly asymmetrical; antennomeres IX and $\mathrm{X}$ elongate-cylindrical; antennomere XI oval, not constricted. Apical maxillary palpomere strongly elongated, conical, pointed, nearly symmetrical.

Thorax. Pronotum with weakly developed scutellar lobe. Pronotal hind angles overlapping base of elytra in repose. Scutellar shield small. Prosternal process rounded in lateral view, truncated apically, edging laterally, without spine-like setae at apex. Scutellar shield small, triangular. Protibial ctenidium absent. Mesocoxal cavities widely separated by more than half coxal cavity width. Metaventral process extending beyond anterior level of mesocoxae, protruding and arcuately lobed anteriorly. Metaventral lines separated from coxal cavities. Anterior margin of metacoxa without emargination sublaterally; metacoxal plate without transverse line; metatibial foreface without apical ctenidium; two metatibial spurs present, nearly equal in length, length of each spur nearly equal to the width of tibial apex. Metatarsi distinctly longer than other tarsi, not compressed; metatarsomere I distinctly longer than metatarsomere II. Epipleura narrowed near metathorax. Elytra with one sutural stria. Tibial spurs formula $0-0-2$.

Abdomen. Five abdominal ventrites approximately equal in length, abdominal ventrite I slightly longer than ventrite II, abdominal ventrite I without paired lines or calli. Ventrites punctured chetae only present on ventrite borders; ventrite $\mathrm{V}$ without grooves or furrows,.

ETYMOLOGY. As the new genus is similar to the genera Litochropus and Neolitochrus, the name is a combination of these generic names.

\section{Neolitochropus hoffeinsorum sp.n.} Figs $1-5$.

MATERIAL. Holotype: CCHH 1206-1. Bitterfeld amber, Late Eocene. Syninclusion: Sciaridae (female). Holotype will be deposited in the amber collection of the Senckenberg Deutsches Entomologisches Institut, Müncheberg, Germany.

DESCRIPTION. Body black, upper side without light light markings, underside brilliant. Total length $1.3 \mathrm{~mm}$. Total length 1.5 times width, width of combined elytra equal to 0.8 length. Length of pronotum equal to 0.6 width.

Head. Eyes medium sized; facets convex; periocular groove absent. Frontoclypeus emarginate above antennal insertion; clypeal apex arcuate truncate. Antennal club 3segmented, club slender, weakly asymmetrical; antennomere XI 2 times longer than antennomere X. Apical maxillary palpomere shorter than previous palpomere.

Thorax. Pronotum strongly transverse, weakly and rarely punctured, with moderately developed scutellar lobe. Procoxal cavity with anterolateral notch-like extension. Proster-

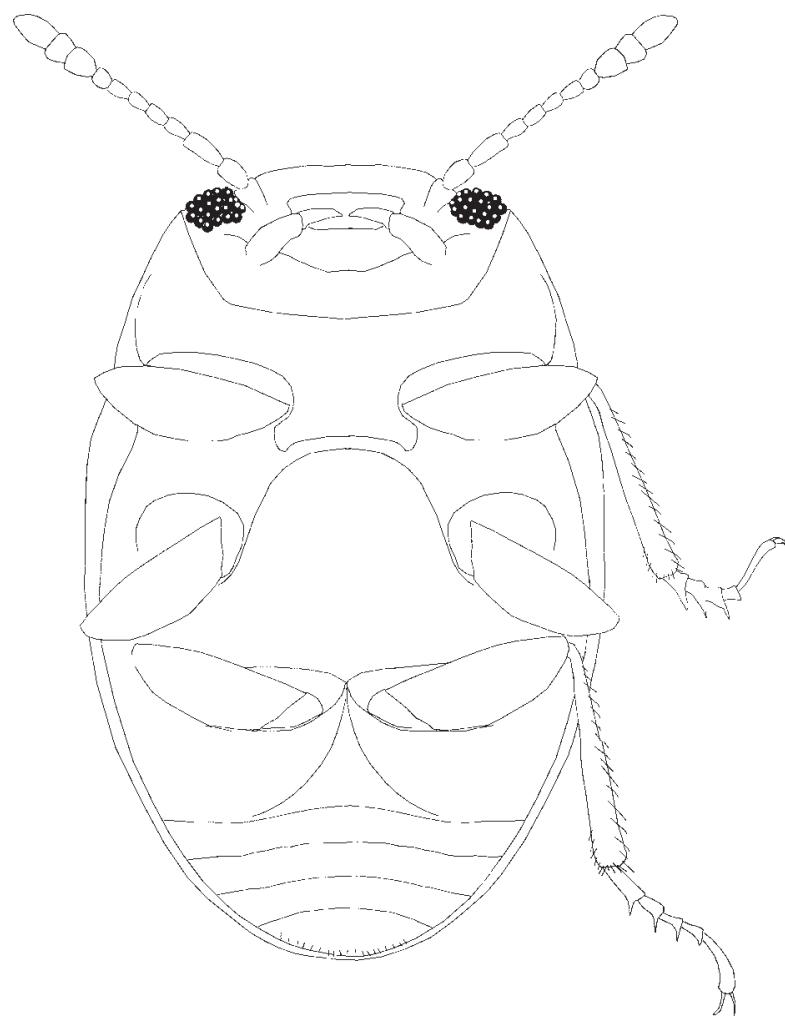

Fig. 5. Neolitochropus hoffeinsorum gen. et sp.n., tracings, ventral view.

Рис. 5. Neolitochropus hoffeinsorum gen. et sp.n., прорисовка, снизу.

nal process without setae at apex. Protrochanter without setae; protibia without ctenidium on front side, slender. Scutellar shield small. Elytron without spectral iridescence, though usually with microsculpture-induced iridescence; with one sutural stria; disc with rudimentary rows of punctures; without transverse strigae.

Mesocoxal cavities widely separated, by more than half coxal cavity width. Mesotibia club-shaped. Mesotarsomere III weakly bilobed. Metaventral plate strongly punctured. Anterior margin of metacoxa without emargination sublaterally; metatibial foreface without apical ctenidium; spurs cylindrical, longest spur shorter than width of tibial apex. Metatibia slender. Tarsal formula 5-5-5 (sex unknown). Metatarsomere I 1.5 times longer than metatarsomere II.

Abdomen. Metaventral postcoxal (femoral) lines separated from mesocoxal cavity margin, arcuate. Ventrites punctured. Ventrite I almost the same width as ventrites II and III combined. Ventrites II, III and IV of approximately equal width. Ventrite $\mathrm{V}$ arcuate, with a series of chetae on the posterior edge.

ETYMOLOGY. The species is named in honour of Christel and Hans Werner Hoffeins.

REMARKS. The syninclusion (Diptera, one female) preserved with the described beetle is a member of the cosmopolitan family Sciaridae, which is very common in the fossil record. Therefore, the syninclusion does not provide further information on the habitat and burial conditions of the beetle.

The following is a key to the genera of the Phalacridae [according to Gimmel, 2013], which are charac- 
terized by the following features: protibia without ctenidium or with obliquely oriented short ctenidium, elytra with less than four discal striae, and metatarsomere I as long as or longer than metatarsomere II (i.e. members of the Litochropus genus group) :

1. Meso-metaventral margin emarginate at apex for reception of protrusive prosternal process (prosternal process often with horizontally laminate structure) or truncate, not extending anteriorly beyond mesocoxae; metaventral lines not separated from coxal cavities; elytra with spectral iridescence (sometimes weak). Metatarsomere I as long as metatarsomere II ........ Entomocnemus Guillebeau, 1894

- Meso-metaventral margin truncate or lobed, extending anteriorly beyond mesocoxae, prosternal process not protruding; if lobe truncate, metaventral lines separated from coxal cavities and spectral iridescence absent; elytra with or without spectral iridescence. Metatarsomere I longer than metatarsomere II ...................................... 2

2. Protibia with short ctenidium, with oblique row of 5-10 spines subapically; metaventral lines not separated from coxal cavities ......................... Litochrus Erichson, 1845

- Protibial ctenidium absent, without spurs or with 1 or 2 spines at outer apical angle of tibia; metaventral lines separated from coxal cavities (but often difficult to observe).

3. Mesotibia without apical spurs. Metatarsomere I 1.5 times longer than metatarsomere II ..... Neolitochropus gen.n.

- Mesotibia with apical spurs. Metatarsomere I twice the length of metatarsomere II

4. Mesoventral plate extending posteriorly to metaventral process, borders complete (difficult or impossible to see when beetle is in repose). Elytra not iridescent, with distinct transverse strigae over virtually entire surface. Eye indistinctly emarginate medially. Elytra usually with 1 engraved sutural stria (occasionally with 2 ). Mesotibia with only 1 apical spur ( 2 in Australasian forms). Longest metatibial spur not longer than width of tibial apex. Generally more globular species ..... Litochropus Casey, 1890

- Mesoventral plate with lateral borders becoming obsolete posteriorly, not reaching metaventral process. Elytra iridescent, without transverse strigae. Eye distinctly emarginated. Elytra with 2 engraved sutural striae (rarely with 1). Mesotibia with 2 apical spurs. Longest metatibial spur distinctly longer than width of tibial apex. Generally more flattened species ............... Neolitochrus Gimmel, 2013

\section{Discussion}

This is the first discovery of a fossil exotic phalacrid genus in Europe. Extant Litochropus group species are recorded in the New World (Nearctic and Neotropical), eastern and northern Australia, New Guinea, Borneo, and Thailand.

Although all previously known fossils (Phalacrus, Olibrus, and Stilbus) are assigned to extant genera, the identifications of Phalacrus and Olibrus in amber are outdated and have not been recently confirmed by specialists on the group.

Due to the very warm climate of the Paris Basin in the earliest Eocene the fauna of the Oise amber, particularly the Coleoptera fauna, is closer to the modern fauna of tropical regions than that of the Holarctic [Kirejtshuk,
Nel, 2013]. For example, the Melyridae from Oise amber have their modern relatives in more arid areas of the recent Paleotropics; Eumolpinae show some links with groups of the recent Indo-Malayan fauna; Salpingidae (Eopeplus Kirejtshuk et Nel, 2009) are associated with genera now widespread in tropics and subtropics; and the Scarabaeidae (Lebateuchus Montreuil, Genier et Nel, 2010) are connected to genera widespread in the recent Paleotropical region. On the other hand, Upper Eocene ambers are dominated by Holarctic elements; thus, in the well-studied representative collection of Saxon amber ants, Holarctic species dominate in the number of specimens (ratio 6 to 1) although the number of Holarctic species is 1.1 times lower [Perkovsky, 2016]. In the ratio of the Holarctic and tropical species, ants from the Bitterfeld amber occupy an intermediate position between those of the Baltic amber from Gdańsk Bay and southern Danish and Rovno ambers [Perkovsky, 2011, 2016]. The characteristic genus Fallomyrma Dlussky et Radchenko, 2006 , found in Bitterfeld, is one of the most abundant ant genera in the Danish amber, is also common (represented by four species) in the Rovno amber, but is completely absent from the Baltic amber [Perkovsky, 2011, 2016]. The characteristic genus Fallomyrma, found in Bitterfeld, is one of the most abundant genera in the Danish amber, is also common (represented by four species) in the Rovno amber, but is completely absent from the Baltic amber [Perkovsky, 2011, 2016]. Therefore, the discovery of a representative of the mostly tropical Litochropus genus group in the Bitterfeld amber is very interesting from a zoogeographic viewpoint. However, a comparative analysis of various phalacrid faunas from Upper Eocene ambers can only be done after a revision of both the Baltic and Bitterfeld material.

The new species is the 13th beetle species known from the Bitterfeld amber, and the 6th species known only from this amber [Alekseev, 2015]. The genus Neolitochropus is the third monotypic beetle genus known only from Bitterfeld amber (the other two belonging to long-horned beetles).

ACKNOWLEDGMENTS. We are grateful to Christel and Hans Werner Hoffeins (Hamburg, Germany) for providing the material for study. We would like to thank Vitaly Yu. Nazarenko (Schmalhausen Institute of Zoology, Kiev, Ukraine) for kindly taking photographs of the specimen, to Alexandr P. Rasnitsyn (Palaeontological Institute, Moscow) for valuable discussion of the paper, and to Vitaly I. Alekseev (Kaliningrad State Technical University, Russia) for information on the Bitterfeld amber beetles, Sarah Martin (Geological Survey of Western Australia, East Perth, Australia,) for editing of the English.

This study was supported by Research project of Zoological Museum of MSU (AAAA-A16-116021660077-3).

\section{References}

Alekseev V.I. 2015. Preliminary linguistic classification of Latin specific epithets for beetles (Insecta: Coleoptera) from Eocene amber of Central Europe // Zoology and Ecology. Vol.25. No.4. P.373-376. 
Gimmel M.L. 2013. Genus-level revision of the family Phalacridae (Coleoptera: Cucujoidea) // Zootaxa. Vol.3605. No.1. P.1-147.

Hieke F., Pietrzeniuk E. 1984. Die Bernstein-Käfer des Museums für Naturkunde, Berlin (Insecta, Coleoptera) // Mitteilungen aus dem Zoologischen Museum Berlin. Bd.60. Hf.2. S.297-326.

Kirejtshuk A.G., Nel A. 2009. New genera and species of Cucujiformia (Coleoptera, Polyphaga) from lowermost Eocene French amber // Denisia. Vol.26. P.103-118.

Kirejtshuk A.G., Nel A. 2013. Current knowledge of Coleoptera (Insecta) from the Lowermost Eocene Oise amber // Insect Systematics \& Evolution. Vol.44. P.175-201.

Kirejtshuk A.G., Ponomarenko A.G. 2014. [Systematic list of fossil beetles of the suborder Scarabaeina (3rd part of catalogue)]. http://www.zin.ru/animalia/coleoptera/rus/paleosy2.htm

Klebs R. 1910. Über Bernsteineinschlüsse im allgemeinen und die Coleopteren meiner Bernsteinsammlung // Schriften der Physikalischen-Ökonomischen Gesellschaft zu Königsberg. Bd.51. S.217-242.

Lyubarsky G.Yu., Perkovsky E.E. 2011. New species of Stilbus (Coleoptera, Clavicornia, Phalacridae) from the Late Eocene Rovno amber // Vestnik zoologii. Vol.45. No.2. P.187-190.

Montreuil O., Genier F., Nel A. 2010. Lobateuchus, un nouveau genre de «bousier» fossile du nord de la France (Coleoptera: Scarabaeidae, Scarabaeinae) // Annales de la Société Entomo logique de France. Vol.46. P.164-167.
Peris D., Ruzzier E., Perrichot V., Delclòs X. 2016. Evolutionary and paleobiological implications of Coleoptera (Insecta) from Tethyan-influenced Cretaceous ambers // Geoscience Frontiers. Vol.7. No.4. P.695-706.

Perkovsky E.E. 2011. Syninclusions of the Eocene winter ant Prenolepis henshei (Hymenoptera: Formicidae) and Germaraphis aphids (Hemiptera: Eriosomatidae) in Late Eocene Baltic and Rovno amber: some implications // Russian Entomological Journal. Vol.20. No.3. P.303-313.

Perkovsky E.E. 2016. Tropical and Holarctic ants in Late Eocene ambers // Vestnik zoologii. Vol.50. No.2. P.111-122

Spahr U. 1981. Systematischer Katalog der Bernstein und KopalKäfer (Coleoptera) // Stuttg. Beit. Naturk. Ser. B. Geol. Paläontol. Bd.80. S.1-107.

Steiner W.E. Jr. 1984. A review of the biology of phalacrid beetles (Coleoptera) // Wheeler Q., Blackwell M. (eds.). Fungus-Insect relationships: Perspectives in Ecology and Evolution. New York: Columbia University Press. P.424-445.

Švec Z. 2007. Phalacridae // Löbl I. \& Smetana A. (eds.). Catalogue of Palaearctic Coleoptera. Volume 4. Elateroidea - Derodontoidea - Bostrichoidea - Lymexyloidea - Cleroidea - Cucujoidea. Stenstrup: Apollo Books. P.64-65, 506-513. 